\title{
Size at sexual maturity of female crabs Sesarma rectum Randall (Crustacea, Brachyura) and ontogenetic variations in the abdomen relative growth
}

\author{
Maria H. de A. Leme \\ Programa de Pós-graduação em Ciências Ambientais, Universidade de Taubaté. Estrada Municipal Dr. José Luiz Cembranelli \\ 5000,12081-010 Taubaté, São Paulo, Brasil.E-mail: mhleme@uol.com.br
}

\begin{abstract}
The aim of the present study was to ascertain the size at sexual maturity in females of the crab Sesarma rectum Randall, 1840 by comparing gonadal maturity to morphologic maturity (using abdomen-width data). The relative growth of the abdomen was analysed for all growth phases (for each 3-mm carapace width size class), and the slopes of the separate allometric relationships were compared through analysis of covariance (ANCOVA) from $\log _{\mathrm{e}}$-transformed data to detect changes in the level of allometry during ontogeny. The physiological size at maturity (gonadal criteria) was determined through a logistic curve, indicating the size at which $50 \%$ of females presented mature gonads $\left(M_{50}=17.4 \mathrm{~mm} \mathrm{CW}\right)$. The highest allometric levels occurred in growth phases 2 and 3 (body sizes ranging from 15 to $21 \mathrm{~mm} \mathrm{CW}$ ), indicating faster growth of the abdomen during those phases. Phases $1(<15 \mathrm{~mm} \mathrm{CW}$ ) and 4 and 5 (size classes above $21 \mathrm{~mm} \mathrm{CW}$ ) showed isometric growth. In the study area, a mangrove on the northern coast of the state of São Paulo, Brazil, individuals of $S$. rectum began to reach sexual maturity from $15 \mathrm{~mm} \mathrm{CW}$ onward, when the slopes of the relationship of abdomen width to carapace width became positively allometric, indicating a differential growth rate. A gradual decrease in the slope, tending to isometry, occurred during ontogeny, as the animals became larger (older).

KEY WORDS. Allometric analysis, gonadal maturity, Grapsoidea, mangrove crab.
\end{abstract}

RESUMO. Tamanho da maturidade sexual de fêmeas do caranguejo Sesarma rectum Randall (Crustacea, Brachyura) e variações ontogenéticas no crescimento relativo do abdômen. $O$ objetivo do presente estudo foi determinar o tamanho da maturidade sexual em fêmeas do caranguejo Sesarma rectum através de comparações da maturidade gonadal com a maturidade morfológica (usando dados da largura do abdômen). $\mathrm{O}$ crescimento relativo do abdômen foi analisado para todas as fases de crescimento (para cada classe de tamanho de $3 \mathrm{~mm}$ de largura de carapaça) e os coeficientes de regressão foram comparados para cada relação alométrica através de analises de covariância (ANCOVA) após transformação logarítmica dos dados, afim de detectar mudanças nos níveis da alometria ao longo da ontogenia. $O$ tamanho da maturidade sexual fisiológica (critério gonadal) foi determinado através de uma curva logística, indicando o tamanho no qual $50 \%$ das fêmeas apresentaram gônadas maduras $\left(M_{50}=17.4 \mathrm{~mm} L C\right)$. Os maiores níveis alométricos ocorreram nas fases de crescimento 2 e 3 (tamanho de corpo variando de 15 a $21 \mathrm{~mm} \mathrm{LC}$ ), indicando acentuado crescimento do abdômen durante estas fases. Crescimento isométrico ocorreu nas fases $1(<15 \mathrm{~mm} \mathrm{LC}$ ) e fases 4 e 5 (classes de tamanho acima de $21 \mathrm{~mm}$ LC). No local de estudo, um manguezal localizado na costa norte do Estado de São Paulo, indivíduos fêmeas de S. rectum começam a atingir a maturidade sexual a partir de $15 \mathrm{~mm}$ de LC, quando os coeficientes de regressão das relações da largura do abdômen contra a largura da carapaça tornam-se positivamente alométricos, indicando taxa de crescimento diferencial. Uma gradual diminuição na inclinação da reta, tendendo a isometria, ocorre ao longo da ontogenia conforme as fêmeas tornam-se maiores (mais velhas).

PALAVRAS CHAVES. Análises alométricas, maturidade gonadal, Grapsoidea, caranguejo de manguezal.

Determining the size of the sexual maturity of fish and crabs have been a constant by researchers focusing, principally, the management of fishery resources. However, it is useful also for purposes of conservation of biodiversity by characterizing population aspects concerned with abundance and structure since that the amount of mature individuals in a given population is responsible by the future generation. That kind of study gives subside for management of natural stock of animal populations which also must be monitored for ends of habitat conservation. 
In crustaceans, the allometric relationships between body size and various organs have been used to estimate the size at maturity, assuming that secondary sexual traits appear and grow at different rates in the immature and mature phases. The transitional phase in brachyurans involves morphological and morphometric changes which can be detected by inflections or discontinuities in series of linear or curvilinear relationships using bivariate analysis (HAEFNER 1990). For female crabs, abdomen width is the measurement which is most often used to detect the onset of sexual maturity from morphological criteria (Hartnoll 1974, Pinheiro \& Fransozo 1993). However, to ascertain the size at sexual maturity, other criteria must be used, because morphometric maturity may not always correspond to functional maturity (WENNER et al. 1974, ОH \& HARTNOLL 1999). Brachyurans offer the possibility of direct assessment of female functional maturity, because females carry their eggs beneath their abdomen for some period of time. Ultimately, functional maturity of females is realised only when they have extruded and held a clutch of eggs. This criteria to accesses maturity size is often used in studies of population dynamics for practical purposes (Díaz \& Conde 1989, Leme 2002).

Gonadal criteria (or physiological maturity) are also a potential indicator of size at maturity, and have been associated with allometric changes in abdomen width as the female crab matures (KNUdSEN 1960, Hartnoll 1974, 1982, Haefner 1990). Therefore, the use of more than one method to determine size at maturity appears to be appropriate, particularly if these methods are to be used to stipulate the minimum legal size of commercially exploited species (HaEfner 1990, AlunnoBruscia \& Sainte-Marie 1998, Overton \& Macintosh 2002).

For many brachyuran species, morphological changes in the female abdomen may occur abruptly (after the molt to puberty) or may take place progressively, after several molts (HarTnoll 1974, 1982). In grapsoid crabs these abdominal changes are not obvious and the abdomen widths of mature and immature females overlap, which makes it difficult to determine the onset of maturity by means of morphometric methods (HARTNOLL 1965).

Several methods have been applied to solve this problem, such as the MATURE proposed by SOMERTON (1980) or von Bertalanffy's equations. These later method have been criticized (DAY \& TAYLOR 1997) because they employ personal choice of the determinate component in analysis and graphical perception. Cleveland \& McGill (1985) discussed the matter of judging angle rather than tangents (slopes) by personal choice, which leads to distortions in judgments of line segment.

As an alternative to growth models, energetic considerations have been evaluated by assuming that resource allocation changes during the lifetime, and the onset of maturity involves a reduction in the amount of energy devoted to growth. At the onset of reproduction, resources are diverted to the reproductive process (e.g., gonadal maturation, breeding) and the growth rate decreases (CHARNov et al. 2001).
Allometric changes during ontogeny may reflect some functional relationship between body size and physiological or life-history parameters (Gould 1966, КовауASH 2002), or may be a by-product of some underlying mechanism (KozLowski \& WeINER 1997). Accordingly, allometric changes may reflect metabolic rates at several sizes or ages and provide support for biological explanations of life histories.

The aim of the present study was to ascertain the size at sexual maturity in females of the grapsoid crab Sesarma rectum Randall, 1840, by comparing gonadal maturity to morphologic maturity by simultaneously taking morphometric measurements (using abdomen-width data) and observing the developmental stage of gonads. In parallel, the relative growth of the abdomen was analised in phases, and the slopes of the separate allometric relationships were compared to detect changes in the degree of allometry during ontogeny.

\section{MATERIAL AND METHODS}

Females of Sesarma rectum were collected in the Escuro River mangrove $\left(23^{\circ} 29^{\prime} \mathrm{S}\right.$ and $\left.45^{\circ} 09^{\prime} \mathrm{W}\right)$, Ubatuba, state of São Paulo, Brazil from March 2000 through February 2001.

The widest carapace width $(\mathrm{CW})$ and the abdomen width (AW) of the fifth abdominal somite were measured to the nearest $0.1 \mathrm{~mm}$ using vernier calipers. The stage of gonadal development was checked by means of a stereomicroscope and classified according to shape, colour and size of ovaries, in four different stages: 1) immature (IM), not differentiated; 2) rudimentary (RU), with narrow pale cream or yellow filamentous; 3 ) in development (ID), ovaries bright orange with visible oocytes but still small and; 4) developed (DE), ovaries in advanced stage of maturation and occupying more space in the cephalothorax.

The percentage of mature females (with ID + DE gonads) was calculated for each 1-mm CW size class. The physiological size at maturity was determined by means of a logistic curve, indicating the size at which $50 \%$ of females reach sexual maturity $\left(\mathrm{M}_{50}\right)$.

To determine the morphological size at sexual maturity, the abdomen-width data were plotted against CW, after $\log _{e^{-}}$ transformed data. Separate regression lines were fitted to the plots for each 3-mm CW size class. Through one-way analysis of covariance (ANCOVA) of the $\log _{\mathrm{e}}$-transformed data, these regression lines were tested for equality of slopes and intercepts. The allometric level ( $b$ value) obtained from each equation was tested for significant difference from $1(b \# 1)$ by means of a $t$-test (ZAR 1999).

\section{RESULTS}

A total of 193 females of the crab S. rectum were analised in this work as the gonadal maturation and abdomen measurements simultaneously.

Immature gonads were present in $100 \%$ of individuals with body sizes from 12 to $15 \mathrm{~mm} \mathrm{CW}$. RU and ID ovaries began to 

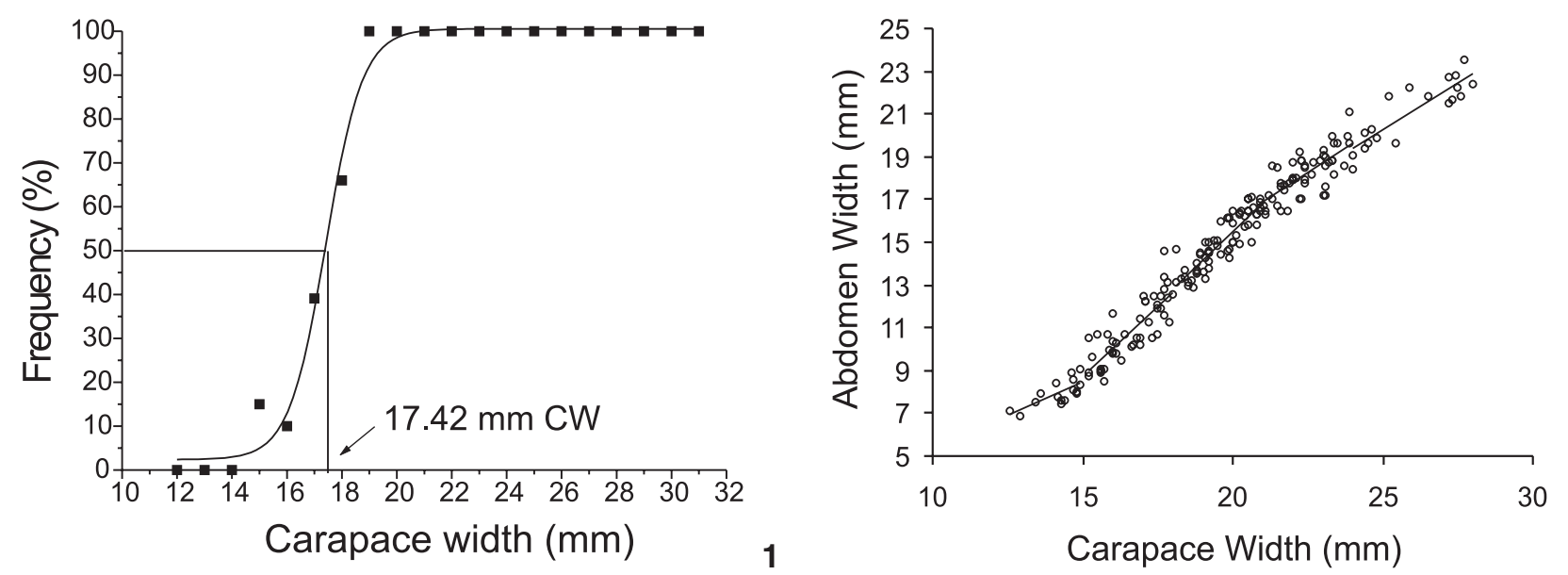

Figures 1-2. (1) Logistic curve fitted based on the proportion of mature individuals (ID and DE gonads) in size classes used to establish the size at $50 \%$ maturity. The arrow indicates the mean size at physiological maturity of Sesarma rectum; (2) relationship between abdomen width and carapace width in females of Sesarma rectum from Ubatuba, Brazil. Separate regression lines were fitted to the plots for each growth phase.

appear in females up to $15 \mathrm{~mm}$ CW. The logistic maturity curve indicated that $50 \%$ of females reach maturity, as defined by the presence of ID and DE gonads, at $17.4 \mathrm{~mm} \mathrm{CW}$ (Fig. 1). This finding is equal to the size of the smallest ovigerous of $S$. rectum sampled in this study (size at functional maturity).

Dispersion diagrams of the AW versus CW of non-transformed data are presented in figure 2 . There are no discontinuities or clear indications of inflection points in the data sets. Therefore, based on the proportions of physiologically mature individuals in size classes (Fig. 1), the individuals were categorized into five size classes, each of $3 \mathrm{~mm} \mathrm{CW}$, which are termed "phases". Phase $1(\mathrm{CW}=12$ to $<15 \mathrm{~mm})$ included physiologically immature individuals, phase 2 ( $\mathrm{CW}=15$ to $<18$ $\mathrm{mm}$ ) included the size determined by the logistic equation were $50 \%$ of females are mature, phase $3(\mathrm{CW}=18$ to $<21 \mathrm{~mm})$ included some few immature and most of mature individuals, and phases 4 and 5 (CW $=21$ to $<24 \mathrm{~mm}$ and 24 to $<27 \mathrm{~mm}$, respectively) included only mature females.

Allometric regression lines were fitted for each phase (see Tab. I), and the allometric level obtained for each one was tested by the difference from the theoretical slope $\left(\mathrm{H}_{0}: \mathrm{b}=1\right)$ by Student's t-test to determinate the allometric growth type. Phase 1 (immature individuals only) was isometric (t-test, $\mathrm{p}<0.05$ ). The highest allometric levels occurred in phases 2 and 3 (body sizes ranging from 15 to $21 \mathrm{~mm} \mathrm{CW}$ ), indicating faster growth of the abdomen in those phases. Phases 4 and 5 showed isometry, and there was no significant difference between them (ANCOVA, $\mathrm{F}=0.026$, d.f. $=1,66, \mathrm{p}=0.86$ ). The slopes indicated no significant difference between phases 2 and 3 (ANCOVA, $\mathrm{F}=$ 0.991 , d.f. $=1,103, \mathrm{p}=0.68$ ), but these differed from phases 4 and 5 (ANCOVA, $\mathrm{F}=6.26$, d.f. $=3,169, \mathrm{p}=0.0007$ ). Grouping phases 4 and 5 resulted in the equation $\ln \mathrm{AW}=1.04 \operatorname{lnCW}-0.334$, indicating that in the size classes containing only mature females, the relative growth of the abdomen was isometric $(b=1$, t-test, $\mathrm{p}>0.05)$.

\section{DISCUSSION}

The onset of both physiological and morphological maturity of $S$. rectum occurs within the same size class $(\mathrm{CW}=15$ to $18 \mathrm{~mm}$ ). The smallest ovigerous female found in this work had $17.4 \mathrm{~mm} \mathrm{CW}$ (functional maturity size), which coincides with the maturity size found by gonadal criteria.

Allometric analysis of abdomen width against carapace width shows that females with 18-21 mm CW still show signs of differential growth presenting positive allometry. Above this size class, the abdomen growth rate diminishes in relation to carapace width showing isometric growth. Such finding indicates that morphological maturation of abdomen might be incomplete yet when females attain the functional maturity and, females with indeterminate growth may continue to enlarge the incubation space (OH \& HarTNOLl 1999, КотB \& HarTnOLL 2002).

This result differ from those of SILva \& CHACur (2002) which reported the morphologic maturity size of $13.3 \mathrm{~mm} \mathrm{CW}$ for $S$. rectum and, they found positive allometry of the abdomen width for both young and adult females. Such results implicate that energy budget no change over the ontogeny (CHARnov et al. 2001). On the other hand, these variations on the onset of maturity size may occur due abiotic factors acting on local and seasonal basis, which may have influence on growth rates (WENNER et al. 1974).

In brachyurans, the abdomens of adult females are adapted for reproduction and egg incubation (HARTNOLL 1985). Because allometric variations during ontogeny could be associated with the reproductive strategy of a species (HARTNOLL 
Table I. Regression equation and allometric level ( = isometric, + positive allometry) determined for each growth phase of females of Sesarma rectum. (n) Number of individuals, ( $r$ ) correlation coefficient.

\begin{tabular}{|c|c|c|c|c|c|c|}
\hline Phases/CW range $(\mathrm{mm})$ & Equation $(\operatorname{Ln} y=b \ln x+a)$ & $\mathrm{n}$ & $r$ & F-value & $p$ & Allometric level \\
\hline Phase $1(12 \dashv 15)$ & $\ln A W=1.091 \ln C W-0.823$ & 16 & 0.74 & 16.69 & $<0.01$ & $=$ \\
\hline Phase $2(15 \dashv 18)$ & $\ln A W=1.979 \operatorname{lnCW}-3.182$ & 45 & 0.82 & 86.86 & $<0.001$ & + \\
\hline Phase $3(18 \dashv 21)$ & $\ln A W=1.741 \mathrm{lnCW}-2.475$ & 62 & 0.88 & 200.80 & $<0.001$ & + \\
\hline Phase $4(21 \dashv 24)$ & $\ln A W=1.130 \ln C W-0.617$ & 52 & 0.73 & 58.43 & $<0.001$ & $=$ \\
\hline Phase $5(>24)$ & $\ln A W=1.094 \operatorname{lnCW}-0.516$ & 18 & 0.87 & 50.21 & $<0.001$ & $=$ \\
\hline
\end{tabular}

1985), such variations might also reflect differential investment (age or size-dependent) of resources in growth (CHARNov et al. 2001). The steeper slopes observed for physiologically immature individuals of $S$. rectum, demonstrated that proportionally more resources had been allocated to body growth. A gradual decrease in slope, tending to isometry, occurred during ontogeny as the animals became larger (older). Thus, the changes in slope may reflect changes in both growth rates and molt increment since the rate at which a crustacean grows depends on intermolt period and molt increment. In brachyurans with indeterminate growth, i.e., which continue to molt after reaching the mature size (HARTNOLL 1985), the intervals between molts become longer and the molt increment decreases as the animal grows. In females these events are more evident due to the egg incubation period, which is an antagonistic event with growth (Adiyodi \& Adiyodi 1970, Fingerman 1987). Moreover, the allocation of resources for somatic growth in immature individuals can differ from the somatic investment of adults, because the adults must allocate resources for reproductive purposes (TuOMi et al. 1983). Allometric analyses contribute to the clarification of many biological events concerned with the life cycle of animals (Gould 1966). In this study, it was identified three changes in allometry of the abdome-width relationship. These changes have been detected in anothers works on brachyurans and are related as immature, prepubescent and adult stages of life cycle (Hartnoll 1982, Alunno-Bruscia \& SainTeMARIE 1998). A marked positive allometry occurs in the transitional phases of immature to mature females, which concerned with the prepuberal phases or where the maturity molt occur. For $S$. rectum, there is not a marked maturity molt with abrupt changes of abdomen shape. So, we conclude by this work that the morphologic maturity molt of $S$. rectum occur between the size interval of 15-18 $\mathrm{mm} \mathrm{CW}$, and the morphological changes of abdomen are associated with gonadal development.

\section{ACKNOWLEDGEMENTS}

This work was supported by FAPESP, through research grants \# JP 99/10267-5 and \# 99/13030-6. I am grateful to Dr I. A. Martins, Dr V. J. Cobo, and the students at the Laboratory of Zoology of the UNITAU for their assistance in collecting samples. I also thank the Pró-reitoria de Pesquisa e Pós-Graduação (PRPPG) and the Department of Biology of the University of Taubaté for their hospitality and logistical support.

\section{REFERENCES}

Adiyodi, K.G. \& R.G. Adiyodi. 1970. Endocrine control of reproduction in decapod Crustacea. Biological Reviews of the Cambridge Philosophical Society, Cambridge, 45: 121-165.

Alunno-Bruscia, M. \& B. Sainte-Marie. 1998. Abdomen allometry, ovary development, and growth of female snow crab, Chionoecetes opilio (Brachyura, Majidae), in the northwestern Gulf of St. Lawrence. Canadian Journal of Fisheries and Aquatic Sciences, Ottawa, 55: 459-477.

Charnov, E.L.; T.F. Turner \& K.O. Winemiller. 2001. Reproductive constraints and the evolution of life histories with indeterminate growth. Proceedings of the National Academy of Sciences of the United States of America, Washington, 98: 9460-9464.

Cleveland, W.S. \& R. McGill. 1985. Graphical perception and graphical methods for analyzing scientific data. Science, Washington, 229: 828-833.

DAY, T. \& P.D. TAYLOR. 1997. von Bertalanffy's growth equation should not be used to model age and size at maturity. American Naturalist, Chicago, 149: 381-393.

Díaz, H. \& J.E. Conde. 1989. Population dynamics and life history of the mangrove crab Aratus pisonii (Brachyura, Grapsidae) in a marine environment. Bulletin of Marine Science, Miami, 45: 148-163.

Fingerman, M. 1987. The endocrine mechanisms of crustaceans. Journal of Crustacean Biology, Lawrence, 7: 1-24.

Gould, S.J. 1966. Allometry and size in ontogeny and phylogeny. Biological Review, Cambridge, 41: 587-640.

Haefner JR., P.A. 1990. Morphometry and size at maturity of Callinectes ornatus (Brachyura, Portunidae) in Bermuda. Bulletin of Marine Science, Miami, 46 (2): 274-286.

Hartnoll, R.G. 1965. Notes on the marine grapsid crabs of Jamaica. Proceedings of the Linnean Society of London, London, 17: 113-147.

HarTNOLL, R.G. 1974. Variation in growth pattern between some secondary sexual characters in crabs (Decapoda, Brachyura). Crustaceana, Leiden, 27, 131-136.

Hartnoll, R.G. 1982. Growth, p. 111-196. In: D.E. Bliss \& L.G. 
ABELE (Eds). The biology of Crustacea: embryology, morphology, and genetics. New York, Academic Press, vol. 2, 440 p.

HarTnOLL, R.G. 1985. Growth, sexual maturity and reproductive output, p. 101-128. In: A.M. WenNER (Ed). Factors in adult growth. Rotterdam, Balkema, vol. 3, 362p.

Knudsen, J.W. 1960. Reproduction, life history, and larval ecology of the California Xanthidae, the pebble crabs. Pacific Science, Honolulu, 14: 3-17.

KoвAYASHI, S. 2002. Relative growth pattern of walking legs of the Japanese mitten crab Eriocheir japonica. Journal of Crustacean Biology, Lawrence, 22, 601-606.

Kotв, M.M.A. \& R.G. Hartnoll. 2002. Aspects of the growth and reproduction of the coral gall crab Hapalocarcinus marsupialis. Journal of Crustacean Biology, Lawrence 22: 558-566.

KozlowsKi, J. \& J. WeIner. 1997. Interspecific allometries are byproducts of body size optimization. American Naturalist, Chicago, 149: 352-380.

LEME, M.H.A. 2002. A comparative analysis of the population biology of the mangrove crabs Aratus pisonii and Sesarma rectum (Brachyura, Grapsidae) from the northern coast of São Paulo State, Brazil. Journal of Crustacean Biology, Lawrence, 22 (3): 553-557.

OH, C.W. \& R.G. HARTNOLL. 1999. Size at sexual maturity, reproductive output, and seasonal reproduction of Philocheras trispinosus (Decapoda) in Port Erin Bay, Isle of Man. Journal of Crustacean Biology, Lawrence, 19 (2): 252-259.

Overton, J.L. \& D.J. Macintosh. 2002. Estimated size at sexual maturity for female mud crabs (genus Scylla) from two sympatric species within Ban Don Bay, Thailand. Journal of Crustacean Biology, Lawrence, 22 (4): 790-797.

Pinheiro, M.A.A. \& A. Fransozo. 1993. Relative growth of the speckled swimming crab Arenaeus cribrarius (Lamarck, 1818) (Brachyura, Portunidae), near Ubatuba, State of São Paulo, Brazil. Crustaceana, Leiden, 65: 377-389.

Silva, S.M.J. \& M. M. Chacur. 2002. Population biology of Sesarma rectum Randal, 1840. (Decapoda, Grapsoidea, Sesarmidae) at Itamanbuca mangrove in northern littoral of São Paulo state, Brazil. Nauplius, Botucatu, 10 (1): 47-51.

Somerton, D.A. 1980. A computer technique for estimating the size of sexual maturity in crabs. Canadian Journal of Fisheries and Aquatic Sciences, Ottawa, 37: 1488-1494.

TuOmi, J.; T. HaKala \& E. Haukioja. 1983. Alternative concepts of reproductive effort, costs of reproduction, and selection in life-history evolution. American Zoologist, Thousand Oaks, 23: 25-34.

Wenner, A.M.; C. Fusaro \& A. OAten. 1974. Size at onset of sexual maturity and growth rate in crustacean populations. Canadian Journal of Zoology, Ottawa, 52: 1095-1107.

ZAR, J.H. 1999. Biostatistical analysis. Upper Saddle River, Prentice-Hall, $2^{\text {nd }}$ ed., 663p.

Received in 17.VIII.2004; accepted in 24.V.2005. 